\title{
Colocalization of proenkephalin peptides in rat brain neurons
}

\author{
HENRY KHACHATURIAN, MICHAEL E. LEWIS and STANLEY J. WATSON \\ Mental Health Research Institute, University of Michigan, Ann Arbor, MI 48109 (U.S.A.)
}

(Accepted August 2nd, 1983)

Key words: proenkephalin - Leu-enkephalin - BAM-22P - dynorphin A

\begin{abstract}
A serial, thin-section immunocytochemical study of the anatomical distribution of Leu-enkephalin and BAM-22P (an adrenal proenkephalin peptide) demonstrated that both immunoreactivities occur within the same neurons throughout brain. However, neither peptide immunoreactivity could be observed in neurons containing dynorphin $\mathbf{A}$ immunoreactivity. These results are consistent with the possibility that the enkephalin precursor in brain is similar to that sequenced in adrenal, but fail to support the hypothesis that the dynorphin precursor is a major source of Leu-enkephalin in brain.
\end{abstract}

The nature of the precursor for the opioid peptides methionine (Met)- and leucine (Leu)-enkephalin in central nervous system is a question of considerable complexity and interest. Recently, significant advances have been made with the elucidation of the structure of the mRNA coding for pre-proenkephalin in bovine adrenal and human pheochromocytoma $4,6,15$; the precursor contains 4 copies of Met-enkephalin and single copies of Leu-enkephalin, Metenkephalin-Arg ${ }^{6}, \mathrm{Phe}^{7}$ and Met-enkephalin-Arg', $\mathrm{Gly}^{7}, \mathrm{Leu}^{8}$. The nervous system contains many peptides with the enkephalin 'core' sequence. From this diversity of opioid peptides there seem to be several logical possibilities for enkephalin biosynthesis in brain. Leu-enkephalin could be produced by cleavage from the prodynorphin products dynorphin $\mathrm{A}$, dynorphin B and $\alpha$-neoendorphin? ${ }^{7}$ Another possibility, which does not exclude the first, is that both Metand Leu-enkephalin might derive from a precursor similar to that found in bovine adrenal. Although adrenal proenkephalin-derived peptides can also be identified in the brain of several species $1,12,14,16,18$, the question of an adrenal-like precursor in brain is still open since the specific brain message has not been sequenced. While Beaumont et al. ${ }^{2}$ have suggested that the brain precursor for the enkephalins is a great deal larger than that found in adrenal, others have suggested similar sizes based on studies of cell-free translation of bovine striatal mRNA coding for brain proenkephalin ${ }^{5,17}$. Furthermore, Kojima et al.12 have found similar chromatographic properties of enkephalin-containing polypeptides from extracts of bovine adrenal and guinea pig adrenal, myenteric plexus and brain, indicating substantial commonality of the proenkephalin structure in these tissues. Our previous immunocytochemical studies with antisera against a proenkephalin adrenal peptide, BAM-22P, and Leu-enkephalin have shown that these two peptide immunoreactivities are similarly localized in many areas of rat brain ${ }^{8-10,20}$, a finding recently confirmed by Bloch et al. ${ }^{3}$. However, none of the above studies demonstrated intraneuronal colocalization of these proenkephalin-derived peptides. In the present study, we report that BAM-22P-like and Leu-enkephalin-like peptides are found in the same neurons in rat brain and therefore may come from a precursor similar to that found in bovine adrenal tissue.

Adult male Sprague-Dawley rats were injected intraventricularly with $50-300 \mu \mathrm{g} / 10 \mu \mathrm{l}$ of colchicine 48 $\mathrm{h}$ prior to sacrifice and were then prepared for immunocytochemistry as described elsewhere ${ }^{11}$. The rats were perfused with neutral buffered $4 \%$ formaldehyde, and the brains were removed, incubated in fixative at $4{ }^{\circ} \mathrm{C}$ for $1 \mathrm{~h}$ and in buffered $15 \%$ sucrose at $4{ }^{\circ} \mathrm{C}$ overnight, and then frozen and stored at $70^{\circ} \mathrm{C}$. Cryostat-cut $4 \mu \mathrm{m}$ sections were thawmounted on subbed slides, stored frozen at $-70^{\circ} \mathrm{C}$, and later processed for immunocytochemistry using the PAP procedure11. Antisera against Leu-enkephalin, BAM-22P, and dynorphin A were used in this 

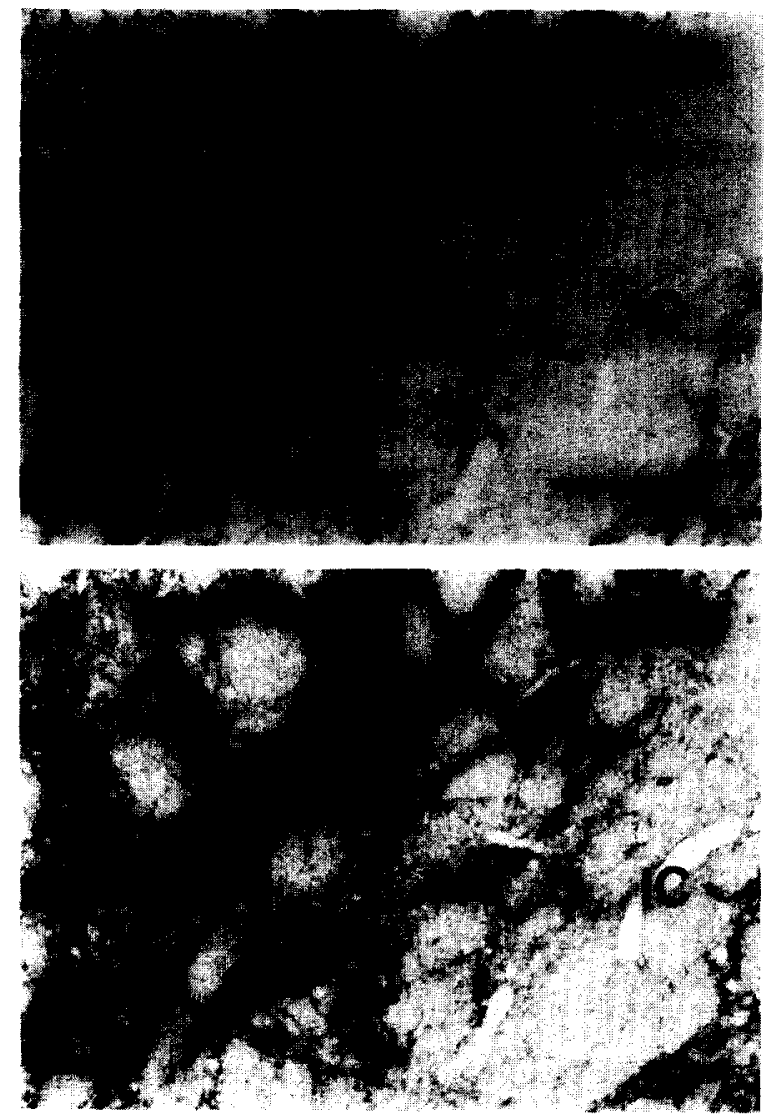

Fig. 1. Comparative distribution of Leu-enkephalin (a) and BAM-22P (b) terminal-like immunoreactivity in serial $4 \mu \mathrm{m}$ sections through globus pallidus. Asterisks indicate common capillary lumen. IC, internal capsule. Bar $=100 \mu \mathrm{m}$.

study. Leu-enkephalin antiserum was produced as described earlier ${ }^{19}$. It was affinity-purified using Leuenkephalin which was $\mathrm{NH}_{2}$-terminal-linked to a cyanogen bromide-activated Sepharose 4B column, and used at $1 / 100$ dilution. Immunocytochemical competition controls revealed that this antiserum is blocked by $1 \mu \mathrm{M}$ Leu- and Met-enkephalin, but not by $20 \mu \mathrm{M}$ BAM-22P, peptide $\mathrm{E}$, dynorphin $\mathrm{A}$ or $\beta$-endorphin. BAM-22P antiserum was used at a dilution of $1 / 500$, and could not be blocked by $20 \mu \mathrm{M}$ concentrations of BAM-12P, peptide $\mathrm{E}, \beta$-endorphin, dynorphin A, Met- or Leu-enkephalin, but could be blocked by $1 \mu \mathrm{M}$ BAM-22P. Antiserum against dynorphin $A$ was used at $1 / 200$ dilution. The antigenic determinant is the $\mathrm{COOH}$-terminus of dynorphin $\mathrm{A}$ since $50 \mu \mathrm{M}$ dynorphin $\mathrm{A}_{1-13}$ does not block it, but 1 $\mu \mathrm{M}$ dynorphin $\mathrm{A}_{1-17}$ does. None of the other opioid peptides mentioned above were capable of blocking the dynorphin antiserum at concentrations of up to 20 $\mu \mathrm{M}$.

In brain, many loci of Leu-enkephalin-positive cells and fibers demonstrated BAM-22P immunoreactivity. The pattern of fiber or terminal-like immunoreactivity was found to be identical in serial sec-
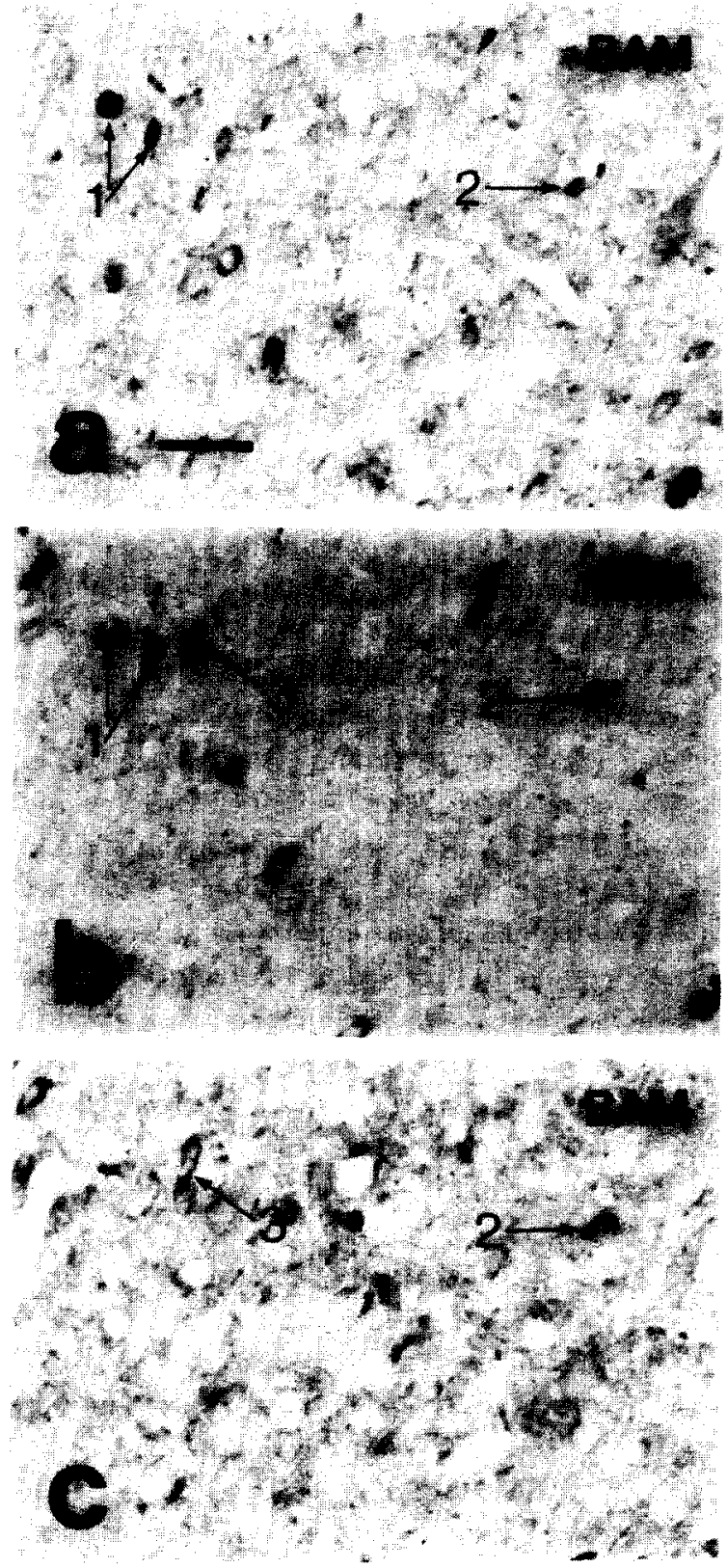

Fig. 2. In the lateral septum, BAM-22P (a, c) and Leu-enkephalin (b) immunoreactivities are colocalized within the same neuronal perikarya, as indicated by numbered arrows in three consecutive serial $4 \mu \mathrm{m}$ sections. Bar $=25 \mu \mathrm{m}$. 

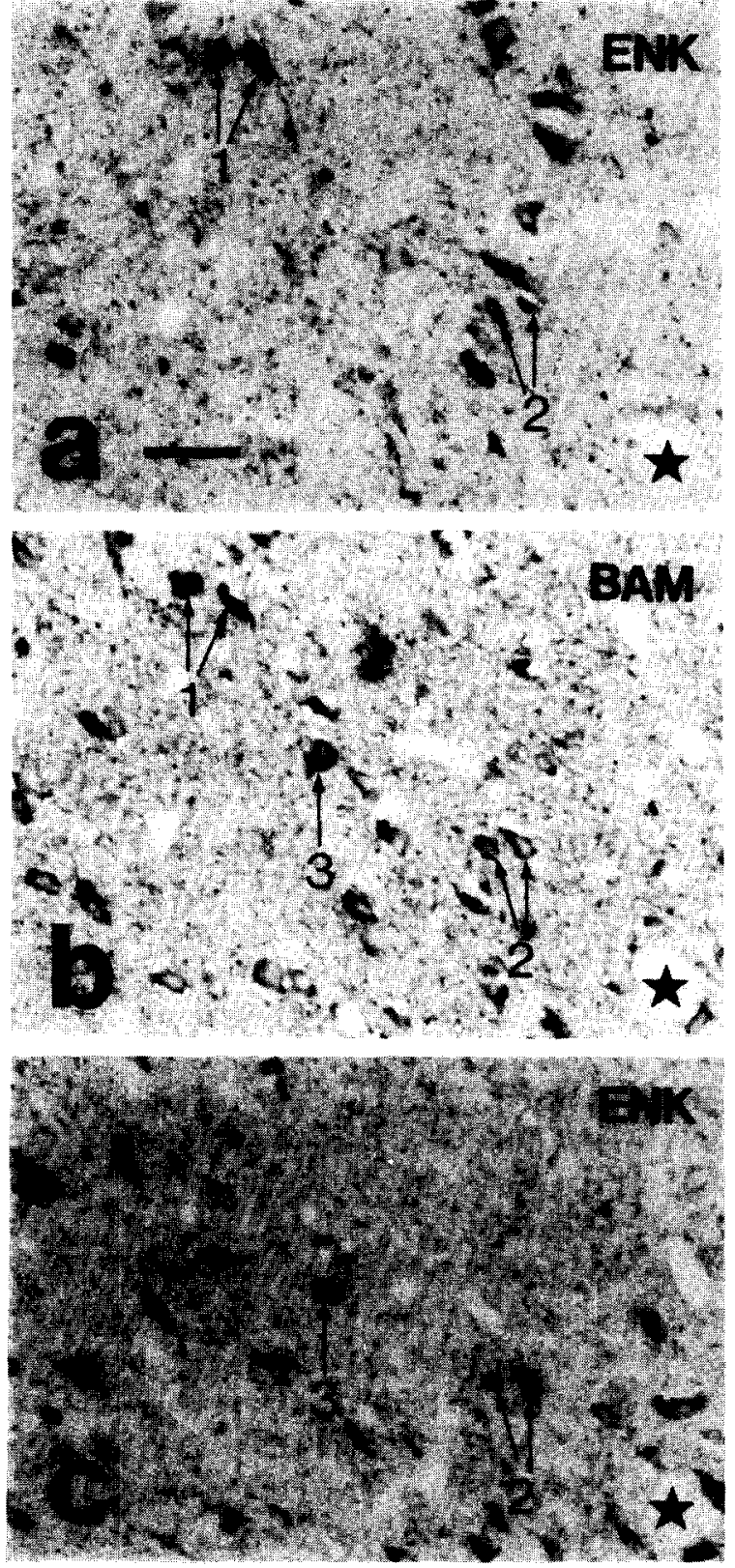

Fig. 3. The ventromedial nucleus of the hypothalamus is seen in three consecutive serial $4 \mu \mathrm{m}$ sections. Leu-enkephalin (a, c) and BAM-22P (b) immunoreactivities are colocalized within the numbered (arrows) perikarya. Asterisks mark a common capillary. Bar $=25 \mu \mathrm{m}$.

tions stained for Leu-enkephalin and BAM-22P (Fig. 1). In widespread regions of the brain, Leu-enkephalin-containing neuronal perikarya were also found to contain BAM-22P immunoreactivity when analyzed in serial sections. These areas from rostral to caudal include the lateral septum (Fig. 2), ventro- medial nucleus of hypothalamus (Fig. 3), periaqueductal gray, nucleus raphe magnus, lateral reticular nucleus, and scattered reticular neurons in the medulla (Fig. 4). In all of the above regions, no exam-
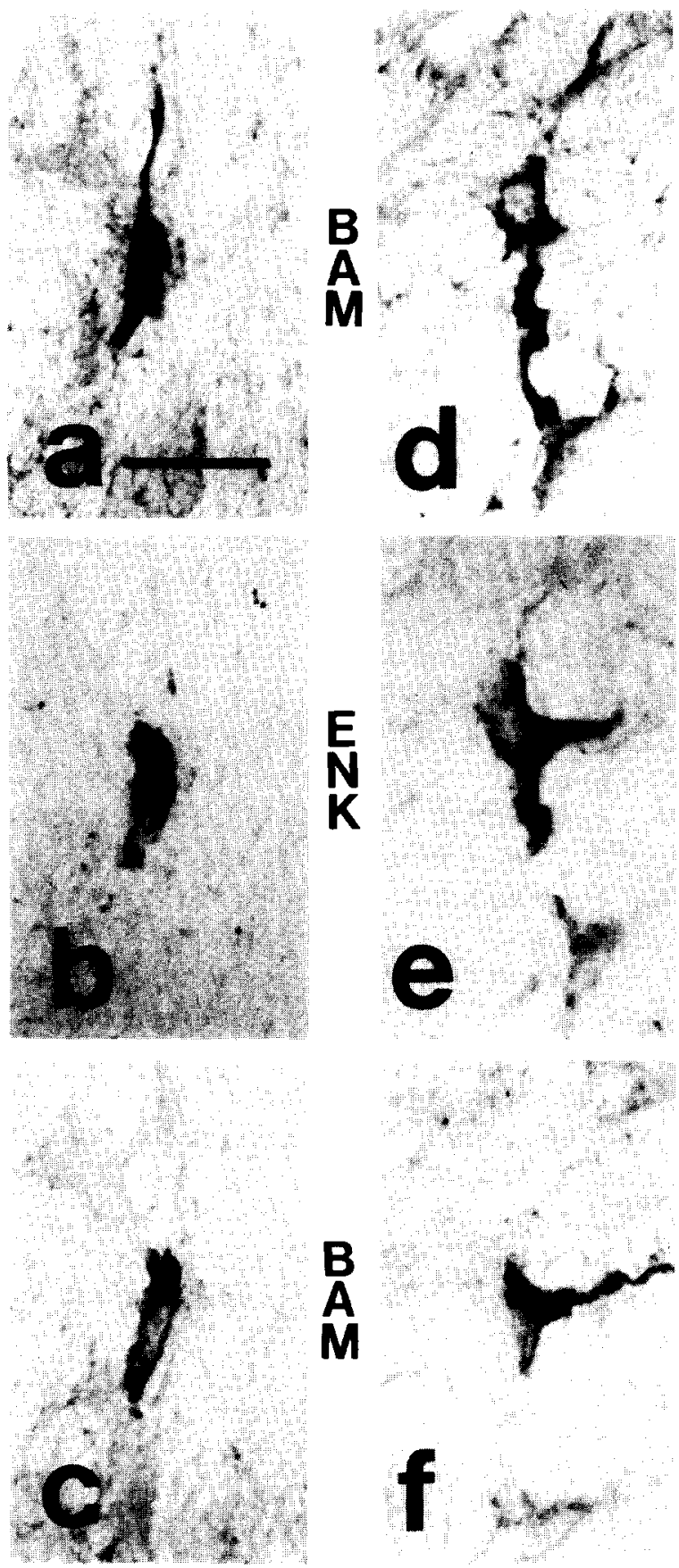

Fig. 4. Colocalization of BAM-22P (a, c, d, f) and Leu-enkephalin (b, e) immunoreactivities in serial $4 \mu \mathrm{m}$ sections through two separate neuronal perikarya $(a-c$ and $d-f)$ in the meduliary reticular formation. Bar $=25 \mu \mathrm{m}$. 
ples of perikaryal colocalization were found with antisera against Leu-enkephalin and dynorphin $A$ or BAM-22P and dynorphin A. This absence of colocalization was observed despite the fact that, in many areas, enkephalin-containing and dynorphin-containing neurons were found to be anatomically adjacent, making distinction of these neurons difficult without the use of serial thin-section analysis. An example of adjacent opioid systems is in the mesencephalic periaqueductal gray where Leu-enkephalinpositive and dynorphin A-positive perikarya are physically contiguous. We had reported previously that there appeared to be a separation between the two neuronal groups, based on serial $20 \mu \mathrm{m}$ section analysis ${ }^{11}$. Based on the present serial $4 \mu \mathrm{m}$ section analysis, it is now clear that these two substances occur in different neuronal populations in the periaqueductal gray.

The colocalization of Leu-enkephalin and BAM22P-like immunoreactivities in the same rat brain neurons is consistent with an enkephalin precursor structure similar to that seen in bovine adrenal and human pheochromocytoma ${ }^{4,6.15}$. It should be pointed out that enkephalin-like immunoreactivity is found in a large number of neuronal and endocrine systems. We have attempted to focus on well described, anatomically divergent enkephalin neurons in an attempt to obtain as broad a sample as possible. Other enkephalin-positive cells should still be evaluated with the antisera used here as well as other sera directed against other regions of the adrenal enkephalin precursor.

The most reasonable conclusion is that the enkephalin precursor in rat brain, bovine adrenal and human pheochromocytoma are similar in several key areas, i.e. they contain Leu-enkephalin and BAM22P-like sequences. A comparison of bovine adrenal and human pheochromocytoma proenkephalin structures shows that the locations of the enkephalin sequences and all major peptide fragments are unchanged. Further, the subtle variants in enkephalinlike peptides and BAM-22P (also a part of peptides E and I), are highly conserved. Our results are consistent with the hypothesis that brain proenkephalin is similar to that found in adrenal, although we cannot, of course, estimate its size using the present approach. Another possibility is that there are actually two routes for enkephalin biosynthesis, the second involving dynorphin A, dynorphin B and $\alpha$-neoendorphin?. All 3 prodynorphin peptides also contain dibasic residues for possible enzymatic cleavage adjacent to the Leu-enkephalin sequence. However, we have not observed colocalization of proenkephalin peptides with prodynorphin peptides in any neuronal group in brain, so our data provide no support for the hypothesis that prodynorphin is a major source of Leu-enkephalin in brain. These findings also indicate that the two genes coding for prodynorphin and proenkephalin are generally unlikely to be equivalently expressed in the same neurons in brain. Of course, we cannot exclude the possibility that other neurons, not examined here, may contain both Leu-enkephalin and dynorphin immunoreactivities.

The finding of a near overlap of BAM-22P/Leu-enkephalin-positive and dynorphin-positive neurons reported here raises questions about the apparent differential localization of Leu- and Met-enkephalin neurons reported previously ${ }^{13}$. If the Leu-enkephalin antiserum used by Larsson et al. ${ }^{13}$ cross-reacted with dynorphin, their finding of separate but nearby Leuand Met-enkephalin immunoreactive neurons might be readily explained. Another possible explanation is that authentic Leu-enkephalin was detected in dynorphin-containing neurons, although we have not observed this colocalization. Given the probable similarity of the brain and adrenal enkephalin precursors, it appears unlikely that Leu- and Met-enkephalin are synthesized from separate precursors in separate neurons in brain. Although our findings indicate the presence of two peptide products of adrenal proenkephalin in the same neurons in brain, it is still possible that the post-translational processing of the precursor differs in adrenal and brain, or in different regions of brain. The exact structure and processing of brain proenkephalin await further clarification.

The authors thank A. Herz and V. Hollt for antiserum to BAM-22P and A. Goldstein for antiserum to dynorphin A. We also wish to thank S. Burke and R. Thompson for technical assistance and $\mathrm{M}$. Ritchie for manuscript preparation. This work was supported by NIDA Grant DA00265 and NIDA Center Grant DA00154 to S.J.W. and NIMH Training Grant MH15794 to H.K. 
1 Baird, A., Ling, N., Bohlen, P., Benoit, R., Klepper, R. and Guillemin, R., Molecular forms of the putative enkephalin precursor BAM-12P in bovine adrenal, pituitary and hypothalamus, Proc. nat. Acad. Sci. U.S.A., 79 (1982) 2023-2025.

2 Beaumont, A., Fuentes, J. A., Hughes, J. and Metters, K. M., Opioid peptide precursors in striatum, FEBS Lett., 122 (1980) 135-137.

3 Bloch, B., Baird, A., Ling, N., Benoit, R. and Guillemin, R., Immunohistochemical evidence that brain enkephalins arise from a precursor similar to adrenal preproenkephalin, Brain Research, 263 (1983) 251-257.

4 Comb, M., Seeburg, P. H., Adelman, J., Eiden, L. and Herbert, E., Primary structure of the human [Met]- and [Leu]enkephalin precursor and its mRNA, Nature (Lond.), 295 (1982) 663-666.

5 Dandekar, S. and Sabol, S., Cell-free translation and partial characterization of proenkephalin messenger RNA from bovine striatum, Biochem. biophys. Res. Commun., 105 (1982) 67-74.

6 Gubler, U., Seeburg, P. H., Hoffman, B. J., Gage, L. P. and Udenfriend, S., Molecular cloning establishes proenkephalin as precursor of enkephalin-containing peptides, Nature (Lond.), 295 (1982) 206-208.

7 Kakidani, H., Furutani, Y., Takahashi, H., Noda, M., Murimoto, Y., Hirose, T., Asai, M., Inayama, S., Nakanishi, S. and Numa, S., Cloning and sequence analysis of cDNA for porcine beta-neo-endorphin/dynorphin precursor, $\mathrm{Na}$ ture (Lond.), 298 (1982) 245-249.

8 Khachaturian, H., Lewis, M. E., Hollt, V. and Watson, S. J., Telencephalic enkephalinergic systems in the rat brain, J. Neurosci., 3 (1983) 844-855.

9 Khachaturian, H., Lewis, M. E. and Watson, S. J., Immunocytochemical studies with antisera against [Leu]enkephalin and an enkephalin-precursor fragment (BAM-22P) in the rat brain, Life Sci., 31 (1982) 1879-1882.

10 Khachaturian, H., Lewis, M. E. and Watson, S. J., Enkephalin systems in diencephalon and brain stem of the rat, J. comp. Neurol., in press.
11 Khachaturian, H., Watson, S. J., Lewis, M. E., Coy, D., Goldstein, A. and Akil, H., Dynorphin immunocytochemistry in the rat central nervous system, Peptides, 3 (1982) 941-954.

12 Kojima, K., Kilpatrick, D. L., Stern, A. S., Jones, B. N. and Udenfriend, S., Proenkephalin: a general pathway for enkephalin biosynthesis in animal tissues, Arch. Biochem. Biophys., 215 (1982) 638-643.

13 Larsson, L.-I., Childers, S. and Snyder, S. H., Methionine and leucine-enkephalin occur in separate neurons, Nature (Lond.), 282 (1979) 407-410.

14 Lewis, R. V., Stein, S., Gerber, L. D., Rubinstein, M. and Udenfriend, S., High molecular weight opioid-containing proteins in striatum, Proc. nat. Acad. Sci. U.S.A., 75 (1978) 4021-4023.

15 Noda, M., Furutani, Y., Takahashi, H., Toyosato, M., Hirose, T., Inayama, S., Nakanishi, S. and Numa, S., Cloning and sequence analysis of cDNA for bovine adrenal preproenkephalin, Nature (Lond.), 295 (1982) 202-206.

16 Rossier, J., Audigier, Y., Ling, N., Cross, J. and Udenfriend, S., [Met]enkephalin-Arg6-Phe ${ }^{7}$, present in high amount in brain of rat, cattle, and man, is an opioid agonist, Nature (Lond.), 288 (1980) 88-90.

17 Sabol, S., Liang, C.-M., Dandekar, S. and Kranzler, L. S., In vitro biosynthesis and processing of immunologically identified methionine-enkephalin precursor protein, $J$. biol. Chem., 258 (1983) 2697-2704.

18 Stern, A. S., Lewis, R. V., Kimura, S., Rossier, J., Gerber, L. D., Brink, L., Stein, S. and Udenfriend, S., Isolation of the opioid heptadecapeptide [Met]enkephalin-[Arg6 $\left.{ }^{6}, \mathrm{Phe}^{7}\right]$ from bovine adrenal medullary granules and striatum, Proc. nat. Acad. Sci. U.S.A., 76 (1979) 6680-6683.

19 Watson, S. J., Akil, H., Sullivan, S. and Barchas, J. D., Immunocytochemical localization of methionine-enkephalin: preliminary observations, Life Sci., 25 (1977) 733-738.

20 Watson, S. J., Khachaturian, H., Akil, H., Coy, D. H. and Goldstein, A., Comparison of the distribution of dynorphin systems and enkephalin systems in brain, Science, 218 (1982) 1134-1136. 